Portland State University

PDXScholar

$1-1-2011$

\title{
Campus Sexual Assault: How Oregon University System Schools Respond
}

Michael William Murphy

Portland State University

Follow this and additional works at: https://pdxscholar.library.pdx.edu/open_access_etds Let us know how access to this document benefits you.

\section{Recommended Citation}

Murphy, Michael William, "Campus Sexual Assault: How Oregon University System Schools Respond" (2011). Dissertations and Theses. Paper 281.

https://doi.org/10.15760/etd.281

This Thesis is brought to you for free and open access. It has been accepted for inclusion in Dissertations and Theses by an authorized administrator of PDXScholar. Please contact us if we can make this document more accessible: pdxscholar@pdx.edu. 
Campus Sexual Assault:

How Oregon University System Schools Respond

\author{
by \\ Michael William Murphy
}

A thesis submitted in partial fulfillment of the requirements for the degree of

\author{
Master of Science \\ in \\ Criminology and Criminal Justice
}

Thesis Committee:

Emily Salisbury, Chair

Robert Lockwood

Danielle McGurrin

Portland State University

(C)2011 


\begin{abstract}
College is usually thought of as a time where students, often living alone for their first time, are encouraged towards healthy risk-taking behavior, as well as social, intellectual, and vocational development. Unfortunately for female students, college becomes the time of their lives where they are exposed to the highest risk of sexual victimization. Many colleges across America have taken steps to address the significant problem of sexual assault on their campuses. However, even with rising concern about the sexual victimization of college students, there remains very little systematic information published about the content of sexual assault policies, protocols and programs that exist on college campuses. Focusing on the seven schools of the Oregon University System (OUS), this study sought to examine the schools' sexual assault policies, as well as their prevention and response efforts to sexual assault. Additionally schools' willingness for assistance and training from Oregon Sexual Assault Task Force (OSATF) was also studied. Specifically, official school sexual assault policies were content analysis and secondary survey data gathered by the OSATF was examined. Results demonstrated that, in most cases, policies of the OUS schools were vague in their definitions of what constituted a sexual assault, and lacked the additional information necessary for victims to respond to their sexual victimization. However, Universities also offered various forms of educational opportunities and awareness raising activities. While this proves promising, there is clearly room for improvement. OUS schools also appeared willing
\end{abstract}


to work with the OSATF to improve the delivery of their sexual assault prevention services. The findings of this thesis are important in directing future actions of the OUS when developing and implementing sexual assault response and prevention strategies. 
Table of Contents

Abstract
List of Tables
Introduction
Literature Review
Methods
Results
Discussion
Conclusion
References
Appendices
A. Definitions of Sexual Assault
B. Definitions of Non-Consent
C. Supplemental Content of Sexual Assault Policies
D. Campus Assessment 2010 Survey


List of Tables

Table 1. Student Population of Oregon University System Schools 38

Table 2. Number of Responses from Oregon University System Schools 39

Table 3. Institutional Definitions of Sexual Assault in Oregon University System Schools 40

Table 4. Institutional Definitions of Non-Consent in Oregon University System Schools

Table 5. Supplemental Content of Sexual Assault Policies in Oregon University System Schools 42-43

Table 6. Groups that are provided educational programming or training within Oregon University System schools 44-45

Table 7. Areas that Oregon University System schools would like training and assistance from the Oregon Sexual Assault Task Force. $46-47$ 


\section{Introduction}

College is usually thought of as a time where students, often living alone for their first time, are encouraged towards healthy risk-taking behaviors, as well as social, intellectual, and vocational development. Unfortunately for female students, college becomes the time of their lives where they are exposed to the highest risk of sexual victimization (Fisher, Cullen, \& Turner, 2000; Fisher, Daigle, \& Cullen, 2010; Koss, Gidycz, \& Wisniewski, 1987). Those students who become victims of sexual assault face potential trauma, psychological distress, and a hindered ability to accurately judge the people and the world around them (Harned, 2004). Many colleges across America have taken steps to address the significant problem of sexual assault on their campuses. For instance, federal legislation has moved to require universities to develop and publish their sexual assault policies and procedures (Jeanne Clery Disclosure of Campus Security Policy and Campus Crime Statistics Act, 20 U.S.C. § 1092(f), 1998).

Even with the rising concern about the sexual victimization of college students, there remains very little systematic information published about the content of sexual assault policies, protocols and programs that exist on college campuses. To address this issue, the United States Congress mandated a study designed to investigate the sexual assault prevention efforts of college campuses. To carry out this study, in 1999 the National Institute of Justice awarded a grant to 
Education Development Center Inc. This thesis is largely based on that study, titled "Campus Sexual Assault: How America's Institutions of Higher Education Respond", authored by Heather Karjane, Bonnie Fisher and Francis Cullen (2001).

In light of their research and recommendations made therein, this thesis explores the policies, procedures and prevention efforts of the seven four-year public universities in Oregon which comprise the Oregon University System (OUS). The OUS recently released a series of guidelines which stipulate the content that should be present in the sexual assault policies of OUS schools, as well as the manner of prevention and resolution strategies. In some areas, the guidelines developed by the OUS are in line with those recommendations of Karjane and colleagues (2001). However, there are other areas where there remains discrepancy, suggesting that Oregon's public universities may not yet act in accordance with the recommendations provided by Karjane and colleagues (2001).

To investigate the policies, procedures and prevention efforts, this thesis utilized official school sexual assault policies as well as a survey developed by the Oregon Sexual Assault Task Force (OSATF). Established in 1999 by then Attorney General of Oregon, Hardy Myers, the OSATF represents a branch of the Oregon Department of Justice. The purpose of the OSATF is to "facilitate and support a collaborative, victim-centered approach to the prevention of and response to adolescent and adult sexual violence" (Oregon Attorney General's Sexual Assault 
Task Force, 2009, p. v). The survey developed by the OSATF was designed to determine whether there is a need for assistance and training in addressing the issues of sexual victimization from the OSATF within Oregon's institutes of higher education.

While this author is aware that males may also be the victims of sexual assault, the vast majority of research on campus sexual assault focuses on female sexual victimization, typically perpetrated by male offenders. It may be possible that many of the issues discussed herein may also apply to male sexual victimization. However, in light of past research, this thesis continues to focus on the issues of female sexual victimization. 


\section{Literature Review}

Since the mid-1980s, the issue of sexual victimization of students has garnered much needed attention, partially through the seminal work of Mary Koss who discovered that as many as one in four college-age women report having had experiences which met the legal definition of rape or attempted rape (Koss et al., 1987). These results were published in several magazines which touted the discovery of an epidemic of rape on college campuses. As these data were surfacing, the media was full of highly publicized sexual assault trials and allegations of reports being mishandled by university officials (Bohmer \& Parrot, 1993; Warshaw, 1988). One such case was the brutal rape and murder of Jeanne Clery in her Lehigh University dormitory room in 1986. In response to public pressure, federal legislation required schools to address the issues of sexual assault on their campuses.

The Student Right-to-Know and Campus Security Act (20 U.S.C. §1092), passed in 1990, was the first piece of legislation designed to address the victimization of college students. The Student Right-to-Know and Campus Security Act requires Title IV eligible schools to publicly disclose crime statistics and crime prevention and security policies and procedures on campus. Title IV eligibility is established through state licensure and academic accreditation, among other things, for the purpose of receiving federal funding. The Student Right-to-Know and Campus Security Act was amended in 1992 to require schools to afford victims specific basic rights. The 1998 
amendment, titled the "Jeanne Clery Disclosure of Campus Security Policy and Campus Crime Statistics Act", emphasized the reporting obligations regarding sexual assault on campus. In 1998, the act became commonly referred to as the Clery Act. The Clery Act has since been amended several more times to include added notice of where public sex offender registration information about offenders on campus may be obtained, and the collection and dissemination of campus hate crime statistics. Schools which fail to meet the requirements of the Clery Act may be subject to a fine of up to $\$ 25,000$ for each violation.

The high rates of sexual victimization among college females have been documented in numerous studies. The first national scale study, conducted by Mary Koss and her colleagues (1987), demonstrated that $16.5 \%$ of female college students reported experiences that met the legal definition of rape or attempted rape within the last year. Further research at individual universities has supported Koss's findings, showing high rates of sexual victimization across various time frames (Combs-Lane \& Smith, 2002; Crawford, Wright, \& Birchmeier, 2008; Hickman \& Muehlenhard, 1997; Marx, Calhoun, Wilson \& Meyerson, 2001; Messman-Moore \& Brown, 2006; Schwartz \& Pitts, 1995). The most recent national scale study found that $2.8 \%$ of 4,466 respondents reported experiencing rape or attempted rape within approximately seven months prior to the survey (Fisher et al., 2010). While recent figures, when compared with figures from the 1980s, indicate a slightly smaller 
problem of sexual victimization, there remains great concern for the well being of students.

Challenging popular belief in stranger rape myths, the majority of sexual assaults against students, approximately $90 \%$, are perpetrated by men who are known to the victim (Fisher et al., 2010; Koss et al., 1987). This type of sexual victimization is now commonly referred to as date rape or acquaintance rape. However, a substantial majority of these victims, approximately three quarters, do not define their experience in legal terms (Koss et al., 1987). Even though victims' experiences legally qualify as a crime, many victims do not label their experience as "rape". These findings are further emphasized when weapons are absent, drugs and/or alcohol are present and physical injury is not apparent (Fisher et al., 2010). All of these are traits common to acquaintance rape (Warshaw, 1988). When victims fail to label their sexual assault experiences as a crime, there are serious implications for reporting campus sexual assault. Victims need to conceptualize their experiences as a crime before they attempt to seek justice for their victimization. Further, rape is identified as the most underreported of all crimes (Diener \& Suh, 1997). Less than 5\% of completed and attempted rapes experienced by college students are ever reported to law enforcement officials (Fisher et al., 2010).

To the extent that a college's sexual assault policies are publicized and used as an educational tool on campus, the definition of what counts as a sexual assault 
becomes extremely important, particularly considering that many women who have experienced an act that legally constitutes as rape do not acknowledge that they are victims of a crime. A college's definition of what constitutes as a sexual assault can be used to educate students on what constitutes a rape. Students should be informed through policy that rape may be committed by someone the victim knows, can occur in the absence of weapons, and may occur when the victim and/or the perpetrator is intoxicated. Specifying acquaintance rape as a separate issue focuses attention on and further reinforces the fact the rape is a crime regardless of the relationship between the victim and offender. Having such policy assists in informing students that the school is receptive to reports of date and acquaintance rape (Karjane, Fisher, \& Cullen, 2001).

Further, as demonstrated in research on the sexual assault of women, using appropriate language is important when defining women's experiences. Using a more general statement that merely asks about being "raped" is open to diverse interpretations. As demonstrated by Koss and her colleagues (1987), many women have experiences which meet the legal definitions of rape or attempted rape; however, they do not define their experiences in legal terms. Koss et al. (1987) was able to more accurately measure the extent of rape by utilizing behaviorally specific language. Behaviorally specific language asks the respondent about their experiences using graphic language which incorporates the necessary elements of a crime. Rather than asking the respondent "Have you ever been raped?" an example of a 
behaviorally specific question from Fisher and colleagues' (2010) study would ask "[...] has anyone made you have sexual intercourse by using force or threatening to harm you or someone close to you? Just so there is no mistake, by intercourse I mean putting a penis in your vagina." This sort of graphic language becomes necessary in research on sexual assault to ensure a shared definition of what legally constitutes a rape.

Using graphic language will become necessary in college sexual assault policy to ensure that students who are victims of date or acquaintance rape will define their experiences as a crime. This will assist in prompting students to report their victimization to campus officials or local law enforcement. Additionally, graphic language will send a clear message to the student body that rape, in any form, will not be tolerated.

In national scale research on campus responses to sexual assault, slightly over $40 \%$ of schools sampled did not send a sexual assault policy on request, nor posted their policy on the internet (Karjane et al., 2001), even though the Clery Act requires schools to make those policies available to the public. The study examined what kinds of sexual assaults were specified as being covered by those policies. Of those schools which sent a policy, one-third used only the generic term of sexual assault or sexual offense, and only $13 \%$ of those schools even defined the term used in their policy. Two-thirds of schools used at least one specific term in their sexual assault 
policies. Among types of schools, four-year public, four-year private nonprofit, and historically black colleges and universities were more likely to mention specific types of sexual victimization. However, this study does not report specific state level data.

Of the schools which did use a specific term to describe what sexual assaults are covered by their policy, approximately $90 \%$ explicitly noted that their policies covered penile-vaginal rape. About $45 \%$ of schools explicitly noted that their policies covered anal or oral penetration and other forms of vaginal penetration, which included the use of fingers or objects. Sixty percent of schools covered unwanted sexual contact. In regards to date and acquaintance rape, almost $78 \%$ did not mention date rape as covered by their sexual assault policies, while almost $47 \%$ of schools did not mention acquaintance rape. Finally, about $95 \%$ of schools did not mention gang acquaintance or date rape, which is rape perpetrated by a group of people known to the victim, in their policies.

Based on their findings, Karjane and her colleagues (2001) published a list of recommendations for the content of sexual assault policy (p. 129). The recommendations represent each school's definition of and the expectations regarding sexual assault.

- Clear operational definitions of what acts constitute a sexual assault

- The prevalence of acquaintance sexual assault

- The circumstances in which sexual assault most commonly occurs

- What to do if you or someone you know is sexually assaulted

- A listing of resources on campus and in the local community 
- The name(s) of a specific person or office to contact when as assault occurs (preferably available 24/7) and when and where to file a complaint

- A statement strongly encouraging victims to report the crime to campus authorities and to the local criminal justice system

- A listing of reporting options, (preferably including an anonymous report option)

- A statement prohibiting retaliation against individuals who bring forth reports of rape of sexual assault and the school's disciplinary actions for retaliation attempts

- A statement exploring that reporting, investigating the report, informal administrative actions (e.g., issuing a no-contact or notrespass order), formal adjudication on campus and criminal justice prosecution are all separate actions (Karjane, Fisher, \& Cullen, 2005)

- Sanctions for violating the sexual misconduct policy (Karjane et al., 2001)

Having an explicit and complete sexual assault policy is important for firmly

establishing the university's stance on sexual assault, as well as educational

purposes. However, many students will never read these policies and if sexually

victimized, may never label their experience as a crime. While university students are unlikely to report their victimization to law enforcement officials, they are far more likely to disclose their experience to a friend. In approximately two-thirds of cases, victims disclosed their experiences to a friend or someone else (Fisher et al., 2010). These findings suggest that fellow students and friends are the group that is most likely to be called upon to provide social support and advice following a sexual victimization. This is particularly important because there is mounting evidence that the response that victims receive following their disclosure has a significant influence on the recovery process and whether or not the victim defines their experience as a crime, and in turn reports the crime (Fisher et al., 2010). 
Students often respond to sexual assault inappropriately, whether is it failure to report their victimization to local law enforcement, or providing inappropriate support for friends who are disclosing their victimization. To ensure that students are making informed decisions about sexual assault, they are in need of training and education which specifically aims to educate them about the definitions of sexual assault and the circumstances in which sexual assault is most likely to occur. Additionally, students need to know what to do if they or someone they know becomes the victim of a sexual assault.

National scale research reveals that students receive sexual assault training in only about 4 in 10 schools (Karjane et al., 2001). Training is provided to students in approximately 7 in 10 four-year public schools. In about half of all those schools which do provide training, participation is voluntary. About 5 in 10 schools provide training to faculty and staff on how to respond to disclosures of sexual assault. In four-year public schools the faculty and staff receive training in approximately 7 in 10 schools. Most often training is provided by faculty and staff members.

The messages of policy, training, and education can be further reinforced through various outlets. For example, students should be exposed to issues of sexual assault at new student orientation, through curricula, resource center trainings, campus events, presentations, and informative campaigns (Karjane et al., 2001). Some promising practices include the use of passive educational flyers, which inform 
students who would otherwise be disinterested in sexual assault until it happens to someone they know. Peer educators and advocates are commonly used to provide interactive education to students, where participants discuss rape myths and apply school policy in various hypothetical situations. Other programs have been designed to specifically target all-male groups. These programs seek to inform males, and build upon the bystander intervention approach which encourages men to identify and intervene in risky situations.

Although campus sexual assault policy, prevention and resolution efforts have been studied nationally, there are little data available on the topic at a state level. This thesis was designed to address that issue by exploring several aspects of sexual assault policies across OUS campuses. First, the content of the sexual assault policies and methods of distribution were investigated. Second, awareness raising events held on OUS campuses were also explored. Lastly, this thesis determined which schools were most in need of training and assistance from the OSATF. 


\section{Methods}

Two separate sources of data were used to answer research questions. First, the sexual assault policies of the Oregon University System were content analyzed. Second, survey data were gathered by the Oregon Sexual Assault Task Force to identify schools which offer sexual assault training and education, as well as sexual assault response and prevention procedures within the Oregon University System's schools. Additionally, the data in the survey were used to identify schools which were most in need of training and assistance from the OSATF.

The Oregon University System consists of seven, four-year public universities across the state of Oregon: Eastern Oregon University (EOU), Oregon Institute of Technology (OIT), Oregon State University (OSU), Portland State University (PSU), Southern Oregon University (SOU), University of Oregon (UO) and Western Oregon University (WOU). These schools represent the population of four-year public universities in Oregon, and served a combined total of over 90,000 students in the $2009-2010$ academic year (see Table 1).

\section{Policy Data}

The sexual assault policies of the OUS schools were identified via the Internet. Policies were located within the Student Code of Conduct accessible through the website of Office of Student Affairs. To ensure that the student code of conduct contained the most extensive sexual assault policy made available by the school, 
searches of the schools' websites using the keywords "Sexual Assault Policy" and "Sexual Misconduct Policy" were conducted. Searches outside of the Student Code of Conduct did not reveal any sexual assault policies which were not already documented within the Student Code of Conduct. Finally, as assurance that schools published their primary sexual assault policies in their Student Code of Conduct, Portland State University was contacted via telephone to ensure that they did not provide a different sexual assault policy outside the Student Code of Conduct. In all cases, the Student Code of Conduct contained the sexual assault policies of schools. Policies were content analyzed to determine their compliance with those recommendations listed by Karjane et al. (2001). Content analysis regarding the institutional definitions of sexual assault was conducted by utilizing a modified version of Section 2 of the "Coding Instrument for Published Sexual Assault Materials" developed by Bonnie Fisher (Karjane et al., 2001; Appendix A).

When reviewing the sexual assault policies of OUS schools, particular attention was paid to the recommendations for sexual assault policy put forth in a study by Heather Karjane and her colleagues (2001, p. 129). Based on the recommendations put forth in Karjane's work, policies were evaluated to determine if they meet those recommendations. An evaluation of schools' compliance with these recommendations was completed using a content analysis tool developed specifically for this thesis (see Appendix B \& Appendix C). 


\section{Survey Data}

In the summer of 2010, the Oregon Sexual Assault Task Force developed a survey titled the "2010 Campus Assessment" (Oregon Attorney General's Sexual Assault Task Force, 2010; Appendix D). This survey was e-mailed to a list of established contacts at universities around Oregon. The OSATF distributed the survey to a total of 21 Oregon universities. For the purposes of this thesis, only the responses from the seven OUS schools were utilized. The survey was delivered by email, along with a request to forward the survey to other people involved in campus affairs, as well as to contacts at other schools across Oregon. A follow-up email was sent a month after the first e-mail to request that representatives who had not participated in the survey do so since their response would be valued. The following response statistics relate only to the seven public universities of the OUS. Each of the OUS schools has at least one survey response, giving a $100 \%$ response rate from those schools.

Five survey responses were eliminated due to non-response to the entire survey, which left a total of 33 responses. Table 2 demonstrates that the majority of responses came from two schools within the OUS. Specifically, nineteen respondents associated with the University of Oregon who each completed and returned a survey. Oregon State University delivered eight responses to the survey. There were two respondents from Portland State University. Finally, there was one respondent from 
each of the remaining schools: Eastern Oregon University, Oregon Institute of Technology, Southern Oregon University and Western Oregon University.

To determine the manner in which information regarding sexual assault was distributed to campuses, all responses to questions 3.4 and 4.1 (see Appendix D), were utilized. In order to determine what campus-specific awareness events are held, responses to open ended questions $5.2,5.3,6.1,6.2,7.1,7.2,7.3$, and 7.4 (see Appendix D) were used. Particular attention was given to trends across respondents and schools, as well as the innovative ideas presented. When considering which schools were most in need of training and assistance in improving and implementing their sexual assault policies and procedures, the responses to five questions were analyzed. The five survey items analyzed were $2.4,2.6,5.4,6.3$, and 7.5 (see Appendix D).

Because some schools returned more than one response to the survey, there were instances where there was disagreement between respondents about the answers to a survey question. Therefore, when the results were presented, it was determined that the answer most frequently chosen by the group of respondents would become the representative answer for that particular university. Further, while "I don't know" and non-responses are presented in the tables, those responses were not counted when determining the majority. 


\section{Results}

\section{Policy Review}

The policies of the Oregon University System schools were content analyzed for their compliance with the recommendations outlined by Karjane et al. (2001). First, the types of sexual assault covered by each school's policy were content analyzed by utilizing a modified version of Fisher's "Coding Instrument for Published Sexual Assault Materials" (see Appendix A). Results from the content analysis in Table 3 reveal that $100 \%$ of schools within the OUS provided at least one specific term in their sexual assault policies. Two schools (29\%) used terms describing penile-vaginal rape, which is sexual intercourse that is perpetrated against the will of the victim (PSU and UO). Eastern Oregon University, Oregon State University and Oregon Institute of Technology, utilize the term rape. However, OSU and OIT failed to define rape in their policies while EOU provided a vague definition. Three schools (43\%) used a term describing anal and/or oral penetration (OIT, PSU and UO), and two schools (29\%) used a term describing other forms of vaginal penetration, such as the use of fingers, mouth, tongue or foreign object (OIT and UO).

Considering the importance of the relationship between the victim and the offender in cases of sexual assault, only 2 of 7 schools (29\%) used the term acquaintance rape in their sexual assault policies (EOU and OIT). None of the schools used the term date rape or gang acquaintance/date rape in their policies. Only 2 of 7 
schools (29\%) explicitly covered in their policies statutory rape or incest (EOU and OIT), categories of sexual assault which must be reported in Clery Act statistics.

The majority of schools (86\%) mentioned sexual contact in their policies, defined as the unwanted touching of intimate body parts. Three of seven schools (43\%) mentioned other forms of sexual misconduct. These other forms of sexual misconduct could include voyeurism, and the nondisclosure of sexually transmitted diseases.

Recent OUS guidelines for addressing sexual assault provide the following definition for use in OUS sexual misconduct policies: "Sexual Misconduct is defined as any sexual contact or sexual behavior that is non-consensual and/or inflicted upon someone who is incapacitated, and/or forced" (OUS Subcommittee on Sexual Assault, 2009, p. 2). The policy goes on to define sexual contact as "the touching of the genitalia, anus, buttocks, breasts or mouth, as well as, any contact for the purpose of sexual gratification" (OUS Subcommittee on Sexual Assault, 2009, p. 2). By utilizing the OUS definitions of sexual misconduct, schools will only be defining sexual contact, as the definition of sexual contact is "unwanted touching of intimate body parts" and the OUS policies leave out any concept of the term penetration. Nonetheless, only 1 of 7 schools (14\%), Southern Oregon University, utilizes the definitions provided by the OUS word for word. 
When defining non-consent, the OUS guidelines provide the following definitions of incapacitation:

"incapacitation is a mental or physical condition that renders a person unable to grant consent. Incapacitation may be a state or condition resulting from the use of alcohol or other drugs, the lack of sleep, sleep and unconsciousness. Incapacitation may also be the result of a cognitive impairment, such as a developmental disability, brain injury, or mental illness" (OUS Subcommittee on Sexual Assault, 2009, p. 2),

and force: "force includes but is not limited to physical force, violence, abuse, threat of force (direct or implied), intimidation, extortion, harassment, coercion, fraud, duress, or pressure" (OUS Subcommittee on Sexual Assault, 2009, p. 2).

When analyzing sexual assault polices for their definitions of non-consent (see Table 4), each of the OUS schools provided a definition of non-consent which captured at least one specific term. At all schools (100\%) in the OUS, sexual assault policies mentioned that intoxication, by alcohol or drugs, may be grounds for establishing non-consent. Six of the schools (86\%) mentioned that both mental disorder and physical impairment can establish non-consent. Finally, 4 of 7 schools (57\%), indicated that the use of force may establish non-consent for sexual activities.

Beyond definitions of sexual assault and non-consent, further content analysis of university policies demonstrated that most of the OUS schools failed to comply with Karjane et al's. (2001) recommendations of the content that should be included (see Table 5). Only two of seven schools (29\%) managed to provide information beyond a definition of the prohibited behaviors in their sexual assault policies. 
Specifically, both Eastern Oregon University and the Oregon Institute of Technology provided information regarding (1) what to do if a someone he/she knows is sexually assaulted, (2) a listing of resources on campus and in the local community, (3) the name(s) of a specific person or office, which is available $24 / 7$, to contact when an assault occurs, (4) a statement strongly encouraging victims to report the crime to campus authorities and to the local criminal justice system, and (5) a listing of reporting options.

The Oregon Institute of Technology goes even further, providing information in their sexual assault policy about the circumstances in which sexual assault most commonly occurs, and a statement prohibiting retaliation against individuals who bring forth reports of sexual assault and the school's disciplinary actions for retaliation attempts. Six of the OUS schools, with the exception of Eastern Oregon University, provided sanctions for violations of prescribed behaviors in their Student Code of Conduct. However, these sanctions were not specific to the violation of the sexual assault policies of the schools, but applied broadly to all violations of the Student Code of Conduct. Only one school (14\%), the Oregon Institute of Technology, provided sanctions specific to the violation of their sexual assault policy.

None of the schools in the OUS provided information on the prevalence of acquaintance sexual assault, nor did they provide a statement explaining that reporting, investigating the report, informal administrative actions (e.g., issuing a no- 
contact or no-trespass order), formal adjudication on campus and criminal justice prosecution are all separate actions. Such a statement is important in that it informs victims that the university's investigative actions and sanctions are entirely separate from those of the criminal justice system, and that actions undertaken by the university may be very different from those of the criminal justice system.

\section{Survey Review}

When reviewing the survey data to determine how information regarding sexual assault was distributed to the general student body, it was revealed that OUS schools provided educational opportunities to most student groups (see Table 6). At all of the OUS schools (100\%), the majority of respondents stated that educational opportunities were offered to first year students. With the exception of the Oregon Institute of Technology, the remaining six OUS schools (86\%) appeared to offer educational opportunities to transfer students, student leaders and student athletes. Regarding residence halls, there were responses from six schools. No survey data were available from Western Oregon University on whether educational opportunities were available in residence halls. However, at each school for which survey data were available, it appeared that educational opportunities were provided to residence halls.

Four schools within the OUS have Greek Life associated with their campuses, the Oregon Institute of Technology, Oregon State University, Portland State 
University and the University of Oregon. Within those four schools, three schools (OIT, OSU and UO) provided survey data regarding whether Greek Life students received education on sexual assault. Of the three schools which provided data, two schools (OSU and UO) appeared to offer sexual assault education to fraternities and sororities, while one school appeared not to offer such educational opportunities to those groups. Educational opportunities were offered to school faculty and staff at two schools (29\%) within the OUS, Oregon Institute of Technology and Southern Oregon University. Although education was offered to at least some students at all schools of the OUS, interestingly, it appeared that sexual assault training was required of students at only one school (14\%), Eastern Oregon University. Results from University of Oregon are split about whether sexual assault training is required of students.

Next, the available campus activities to raise awareness of sexual assault were reviewed. While there were limited data from each school to answer this question, the activities within each school that are mentioned by respondents were reported. Within the OUS schools, there are many programs designed to educate and promote sexual wellness. Some of these programs are ones which are highlighted by Karjane et al. (2001) in their national level study.

The use of sexual assault peer educators is mentioned by respondents from three schools, Oregon State University, Southern Oregon University and University of 
Oregon. Oregon State University's group is called "Every1" and is a peer education group which is "able to organize events and educate through classroom lectures." The Every1 student group educates on both prevention and the available campus resources. Further, Oregon State University also has a student group called "It Starts Now". This group organizes theatre, as well as other events, with the purpose of sexual assault prevention and raising awareness. Southern Oregon University provides little information about their peer educator group beyond a statement that they have peer educators. The University of Oregon has two student groups which seek to educate peers about sexual assault. The Sexual Wellness Advocacy Team (SWAT) and the Alliance for Sexual Assault Prevention (ASAP). SWAT provides an hour-long theatre event to all new students as well as educational workshops. ASAP takes part in organizing the sexual assault awareness month and other activities which occur at the University of Oregon.

A sexual assault awareness month is mentioned by three schools within the OUS (OSU, PSU, and UO). All three of these schools mention hosting an event, during the sexual assault awareness month, called "Taking Back the Night." This event is targeted specifically at raising awareness about sexual violence. During these sexual assault awareness months, campuses will host guest speakers discussing sexual assault. The use of guest speakers on the topic of sexual assault was also mentioned as an awareness raising tool at Southern Oregon University. However, guest speakers may speak on this topic outside of sexual assault awareness month. Additionally, 
Southern Oregon University hosts a Healthy Campus Campaign which "will include a component in prevention of sexual and relational violence."

The use of social marketing and passive programming to raise awareness of sexual assault was mentioned at 3 of 7 schools. Oregon State University, Southern Oregon University and University of Oregon all mentioned that they engaged in social marketing and passive programming. These sorts of activities include displaying flyers and bulletin boards that contain information about sexual assault as well as by providing informational packets to students. Additionally, a safe ride program was established and listed within two schools of the OUS. Oregon State University and University of Oregon offer a safe ride program which provides students safe transportation across campus, with the goal of reducing victimization.

The inclusion of a Sexual Assault Response Team (SART) was mentioned by four schools, Oregon State University, Portland State University, Southern Oregon University and University of Oregon. A SART is a group of professionals, usually consisting of a victim advocate, a Sexual Assault Nurse Examiner, law enforcement and prosecutors, as well as other community members who play an important role in a community's effective response to sexual offenses. The purpose of a SART is to provide a coordinated, multidisciplinary approach that improves the response to sexual assault cases (Oregon Attorney General's Sexual Assault Task Force, 2009, p. 1-2). Eastern Oregon University mentioned that, although they do not have a campus 
SART, they do work closely with their county SART. Respondents from the remaining two schools, Western Oregon University and Oregon Institute of Technology stated that they do not have an active SART on their campus.

Finally, utilizing survey data, it was determined which OUS schools would most like training and assistance from the OSATF (see Table 7). Respondents from each school were asked whether they would like training and assistance from the OSATF in the follow areas:

1. Developing sexual assault policies, getting institutional support, and implementing policies and protocols campus-wide.

2. Implementing Oregon University System Requirements.

3. Mobilizing students around sexual assault prevention and/ or response.

4. Campus Sexual Assault Response Team training and technical assistance.

5. Campus-based sexual assault prevention.

The majority of respondents across all 7 schools of the OUS reported that they would like training and assistance in developing sexual assault policies, getting institutional support, and implementing policies and protocols campus-wide. At 5 of 7 schools (71\%), the majority of respondents stated that they were interested in receiving training and assistance with the implementation of the 2009 Oregon University System guidelines. One school (14\%), Southern Oregon University, stated they were not interested in training in this area. Oregon Institute of Technology 
stated that they did not know whether they wanted assistance in this area. When asked about whether or not schools would be interested in assistance in mobilizing students around prevention and response, the majority of respondents at 6 of 7 schools (86\%) stated that they were interested in receiving assistance from the OSATF. Southern Oregon University stated they were not interested in training and assistance in mobilizing students around prevention and response. Campus SART training was desired by the majority of respondents at 5 of 7 schools (86\%). Oregon Institute of Technology and Southern Oregon University responded with either "I don't know" or a non-response. Finally, when asked about receiving assistance and training in campus-based sexual assault prevention, 4 of 7 schools (71\%) desired such assistance. The remaining three schools (EOU, OIT and SOU) returned either "I don't know" or non-responses to this question.

In some areas, there were as many as $45 \%$ of respondents who were unsure about whether they wanted assistance. However, once "I don't know" and nonresponses were eliminated from analysis, the vast majority, more than $80 \%$, of respondents were interested in assistance from the OSATF across all areas. This demonstrates that there was a large desire across the OUS for the assistance and training which was offered by the OSATF. 


\section{Discussion}

There were several goals of this study. First, it sought to examine the content of campus sexual assault policies and the extent to which they followed evidencebased, nationally recognized guidelines. Second, this study also sought to determine the manner in which information regarding sexual assault policy reached the campus body. Additionally, this study sought to identify the awareness raising activities on campuses, as well as those universities which desired the assistance of the OSATF. Results from the content analysis of campus sexual assault policies showed that no schools within the OUS had implemented all of the policy recommendations of Karjane et al. (2001), and in many cases, policies were lacking definitions of sexual assault which encompass the numerous forms of victimization which may be experienced by students.

Survey data revealed that the majority of student populations appeared to be provided education and/or training about sexual assault on campuses within the OUS. However, this education appeared to be optional and not required of students at these schools. Of further concern is that new faculty and staff did not appear to receive training or education around sexual assault at most schools in the OUS. Awareness raising activities on campuses appeared to be more abundant and diverse on those bigger campuses in the OUS. At each school in the OUS, with the exception of Southern Oregon University, the assistance of the OSATF was desired. This finding 
was true across each area in which the survey assessed a desire for training and assistance (i.e. policy development and implementation, institutional support; implementing OUS guidelines; mobilizing students; campus SART training; and campus based sexual assault prevention). In fact, the majority of respondents across all areas and all schools desired the assistance of the OSATF.

Compared to the results of the national study by Karjane et al. (2001), these results demonstrate that all schools (100\%) in the OUS had a documented sexual assault policy, as compared to $82.2 \%$ of four-year public universities at the national level (Karjane et al., 2001). When comparing definitions of sexual assault, most schools in the OUS failed to mention the various forms of sexual penetration, whereas more than $90 \%$ of four-year public schools in the national sample mentioned penile-vaginal rape, and more than $45 \%$ mentioned anal or oral penetration or penetration with an object (Karjane et al., 2001).The many definitions of sexual assault in the OUS schools, although vague, can be interpreted to apply to many forms of sexual assault. At the national level, $57.1 \%$ of four-year public universities mention acquaintance rape, and $27.6 \%$ mention date rape (Karjane et al., 2001). Within the OUS, only two of seven schools (29\%) mention acquaintance rape, and none of the schools mention date rape.

The findings from the content analysis of sexual assault policies are concerning for a number of reasons. Without strong definitions of what constitutes a 
sexual assault, students may continue to fail to define their experiences as a sexual assault. Thus, the likelihood that students will decide to seek emotional support or physical safety following their victimization may be diminished and many sexual assaults on college campuses may continue to go unreported. Moreover, the fact that the majority of OUS universities fail to mention acquaintance rape in their policies will further point to a limited understanding of sexual assault within the student body.

While not examined in any other studies this author is aware of, the OUS schools typically provided clear definitions of non-consent for sexual conduct in their sexual assault policies. When defining non-consent, most schools recognized the importance of defining non-consent through intoxication as well as physical and mental impairment. However, only four of seven schools (57\%) mentioned that the use of force can establish non-consent for sexual activities. This is surprising considering that the use of force by an offender is typically looked for in cases of sexual assault to show that the victim was not willingly engaging in sexual activity. Further, the OUS guidelines would require all OUS schools to mention that the use of force by an offender may establish non-consent.

Of additional concern is that less than one-third of the OUS schools provided any information beyond a definition of sexual assault in their policies. This compares with national findings that demonstrate that three-quarters of institutes of higher 
education included in their policies specific procedures for contacting authorities if a sexual assault occurs (Karjane et al., 2001). This is concerning because the resources available to students following a sexual assault should be easily accessible and identifiable through policy. There should be a central source, such as the student code of conduct, in which students, staff, and faculty can access the umbrella of campuses policies, resources and responses to sexual assault. Placing all this information together in a single policy should enhance campus consistency and efficiency in addressing reports of sexual assault. Further, to the extent that campus sexual assault policies are used as an educational tool, students will know where to find any information regarding sexual assault on their campus.

It should be noted that the OUS released guidelines in 2009 through which OUS schools should address sexual assault. These guidelines included a definition of sexual assault. Only one school (SOU) within the OUS included these policy guidelines word for word. Nonetheless, when considering the recommendations of Karjane et al. (2001), these OUS guidelines are limited. The OUS should seek to enhance their guidelines for sexual assault policy to include behaviorally specific language and expanded content addressing the other issues mentioned by Karjane et al. (2001), so that OUS schools at least include contact information and the actions a victim should take if they become a victim of sexual assault. 
Sexual assault training and education was offered to students at $100 \%$ of OUS schools, as opposed to $40 \%$ of schools at the national level. However, merely offering educational opportunities to students may be insufficient. The quality of curricula of such educational services will have varying effects on students who participate (Daigle, Fisher \& Stewart, 2009; Gidycz, Layman, Rich, Crothers, Gylys, Matorin, \& Jacobs, 2001; Hanson \& Gidycz, 1993). Some curricula have been found to reduce the likelihood of sexual victimization substantially (see Hanson \& Gidycz, 1993), while other curricula fail to produce lasting reductions in adherence to rape myths (see Gidycz et al., 2001). This thesis shows that within the OUS, education and training is not required of most students. This raises concern, in that often those students who participate in optional sexual assault training are already relatively aware and informed about the issues surrounding sexual assault and rape myths (Schwartz \& DeKeserdy, 1997). Optional participation in sexual assault education and training is often unable to reach those groups which are most in need of it (Schwartz \& DeKeserdy, 1997). For example, peer groups who are strong in rape supportive attitudes and beliefs are unlikely to sign up for and voluntarily participate in education which refutes and dispels those attitudes and beliefs.

Supplementing direct education and training in sexual assault is the awareness raising activities on campuses. There appeared to be at least some awareness raising activities on most campuses of the OUS, such as the use of social 
marketing and passive programming. These activities have been recognized as promising practices at select schools in the Karjane et al. (2001) national study. While survey data revealed that such activities occured most commonly across larger campuses, it is likely that similar activities occurred in some form at most schools in the OUS. As some schools returned fewer survey responses, it is possible that such data on awareness raising activities was not addressed thoroughly by survey respondents. The various forms of awareness raising activities may be important in that they may reach those students who were less likely to participate in formal training and education.

Finally, survey data show that in most cases, the OUS schools were eager for the assistance of the OSATF. Even though the sexual assault policies across OUS campuses are less than ideal, these campuses appeared willing to accept the assistance of the OSATF in improving these policies. Also, while many campuses in the OUS appeared to offer a variety of awareness raising activities and programs, respondents were still eager to receive the assistance of the OSATF to develop and enhance these efforts on campuses. Essentially, despite various strengths and weaknesses in each of the universities' efforts to address sexual assault, it seems that respondents were aware of deficiencies and are willing to work to address their shortcomings. These findings should help establish a case for the OSATF and OUS to 
partner in the development of policies and procedures which more effectively address sexual assault on campuses.

There are numerous limitations to this thesis. First, this thesis sought to examine the content of the sexual assault policies of the seven OUS schools. This thesis identified the types of sexual assault which are mentioned as being covered by each schools sexual assault policy. However, the content analysis tool used in this thesis was unable to differentiate between the use of strong behaviorally specific language and the use of terms which merely describe different sexual behavior. As mentioned earlier in this thesis, the use of strong behaviorally specific language is extremely important in enabling victims of sexual assault to identify their experiences as a crime (Fisher et al., 2010).

Second, this thesis utilized secondary survey data with its own methodological flaws. This secondary survey data were collected using a snowball sampling technique, which may have included respondents who were unable to answer questions in the survey accurately. For example, of concern in this study was the finding that respondents within schools were in disagreement about whether or not certain populations receive sexual assault training or education. This sort of sampling method diminishes the reliability of the findings in this thesis.

A similar problem arose when determining those schools which desired the training and assistance of the OSATF. Respondents were often in disagreement with 
one another, or unsure about whether or not their school wanted training and assistance from the OSATF. The snowball sampling method may have included participants who lacked the authority or knowledge to make an accurate determination about whether the school needed training and assistance in different areas. For example, if a volunteer with the women's center participated in this survey, it is unlikely they would have the authority or knowledge to determine if their school's sexual assault response team is in need of training or assistance.

However, despite these limitations, the findings of this thesis are important in directing future actions of the OUS when developing and implementing sexual assault response and prevention strategies. This thesis also demonstrates the desire for the assistance of the OSATF in improving and supplementing those actions of the OUS. Put together, the OUS and OSATF may be able to reduce the occurrence of sexual assault on OUS campuses, improving the safety of students attending OUS schools.

A follow-up study on this topic would seek to address the limitations of this thesis. It would utilize an enhanced content analysis tool which allowed the researcher to determine those schools which utilize strong behaviorally specific language and those that do not. Second, a future study could develop and implement primary data collection strategies. When determining those educational services and the audiences of those services, a researcher may need to physically observe these education and training activities as they occur. Additionally, as mentioned earlier, the 
curriculum of such training and education programs may provide varying levels of success in changing attitudes and beliefs around sexual assault. A future study of the education and training offered at college campuses, should analyze the curriculum offered within schools to determine those campuses utilizing curriculums which follow best practices. Furthermore, when identifying those schools which may desire training and assistance, future methods would ask specifically those people within a school who oversee such aspects of a school's sexual assault response efforts. Finally, there is a need for further research examining the issues of the sexual victimization of males on college campuses. 


\section{Conclusion}

This thesis sought to expand our knowledge about how universities respond to campus sexual assault. Specifically, this thesis sought to identify the efforts and activities which take place on the seven OUS campuses to address sexual victimization. At the time of this writing, the OUS was also seeking to gain insight into the activities and efforts of their schools in addressing sexual assault. This thesis served its purpose through content analysis of official school policies, as well as through utilization of secondary data to determine the educational opportunities available to students, the awareness raising activities on campuses, and each school's desire for training and OSATF assistance. Findings from this research are useful for the OUS by providing information which can be used to direct future efforts.

Importantly, findings demonstrated that the sexual assault policies in the OUS are lacking in the scope of their definitions of what constitutes a sexual assault. In some schools, the language used was vague enough that it could be interpreted as applying to anything from unwanted sexual touching, to penetration by an object. As demonstrated by Koss et al. (1987), when measuring the scope of rape on college campuses, vague language will not ensure a shared definition of sexual assault. As such, the sexual assault policies of OUS schools should be revised to incorporate behaviorally specific definitions of sexual assault. Further, many OUS schools failed to provide additional necessary information, such as reporting options and contact 
information, in their sexual assault policies. Without this information, victims of sexual assault may struggle to identify how or where to report their victimization and how to access the resources available to victims on their campus.

Educational opportunities regarding sexual assault were available to almost all student groups across the OUS. This proves promising; however these educational opportunities are not required of students, and therefore, may not reach the high risk populations. Additionally, the content of the educational opportunities still requires examination. To supplement formal education and training of campuses, many campuses are engaging in various campus based activities designed to address and raise awareness around sexual assault. These sorts of activities, in combination with formal education and training will help teach and reinforce in students knowledge which may prevent future sexual assaults. Finally, while each of the OUS campuses has its various strengths and weaknesses, it appears that most campuses in the OUS reported their willingness to collaborate with the OSATF to improve the delivery of their sexual assault prevention and response services.

The findings of this study demonstrated that the OUS is taking steps to address sexual assault on college campuses. There remains room for improvement, but campuses appear willing to work towards a better system for further reducing the prevalence of sexual assault. 
Table 1. Student Population of Oregon University System Schools

\begin{tabular}{|l|c|}
\hline University & $\begin{array}{l}\text { Student } \\
\text { Population }\end{array}$ \\
\hline Eastern Oregon University & 3,957 \\
Oregon Institute of Technology. & 3,927 \\
Oregon State University & 22,580 \\
Portland State University & 27,972 \\
Southern Oregon University & 5,104 \\
University of Oregon & 22,386 \\
Western Oregon University & 5,654 \\
\hline Total & 91,580 \\
\hline & ${ }^{1}$ Student populations in the fourth week of Fall term 2009. \\
\hline
\end{tabular}


Table 2. Number of Responses from Oregon University System Schools

\begin{tabular}{|l|c|}
\hline University & $\begin{array}{l}\text { Response } \\
\text { Count }\end{array}$ \\
\hline Eastern Oregon University & 1 \\
Oregon Institute of Technology & 1 \\
Oregon State University & 8 \\
Portland State University & 2 \\
Southern Oregon University & 1 \\
University of Oregon & 19 \\
Western Oregon University & 1 \\
\hline Total & 33 \\
\hline
\end{tabular}




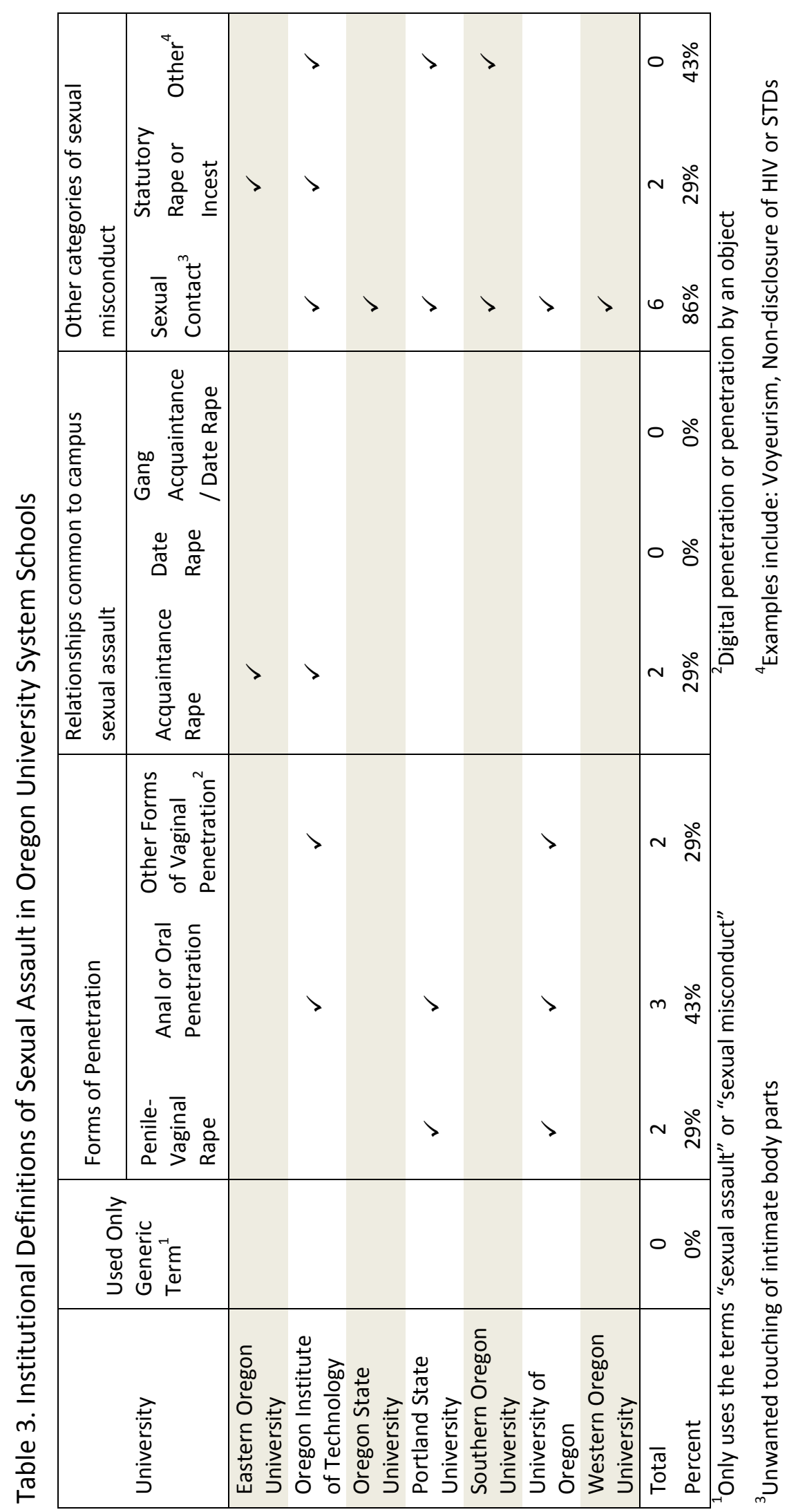




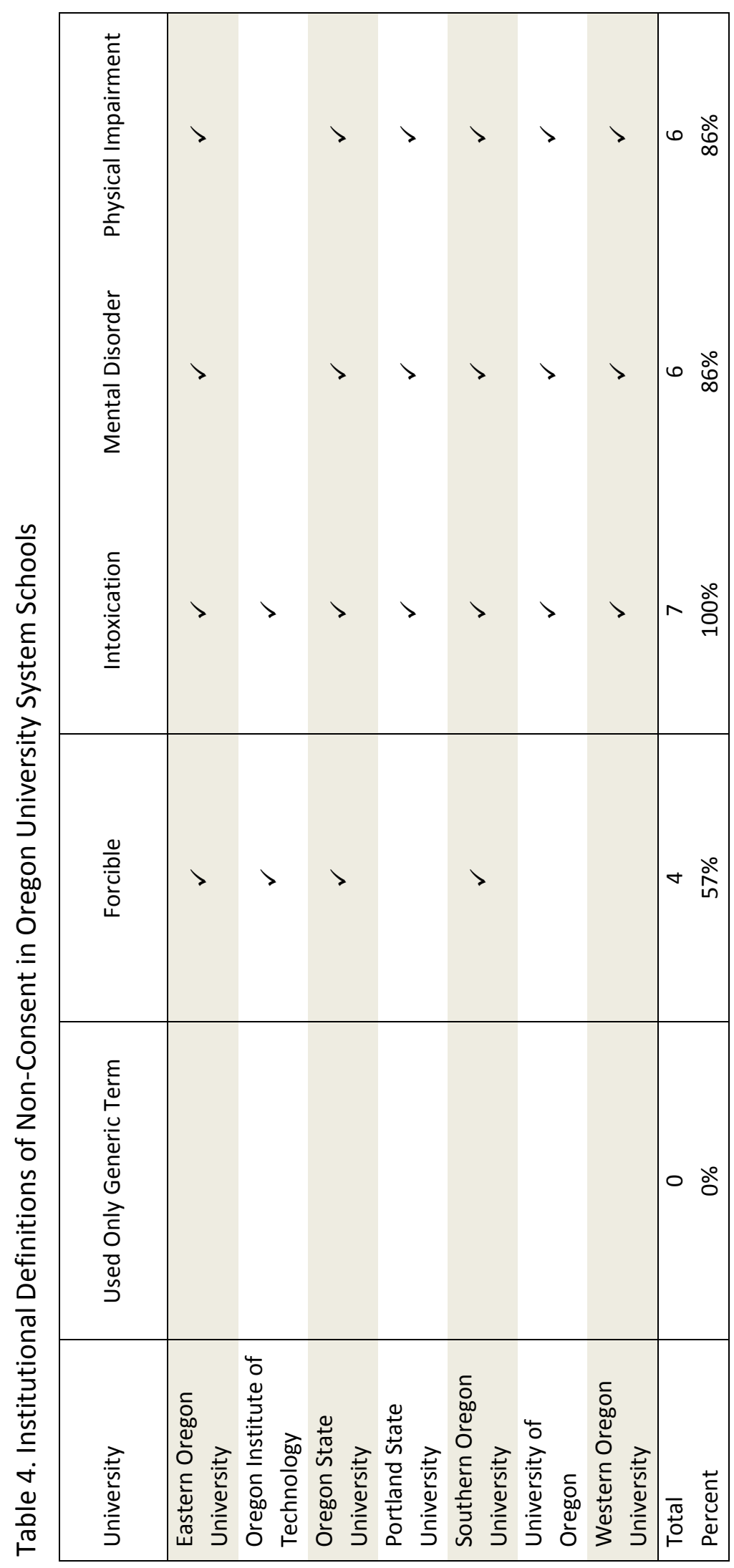




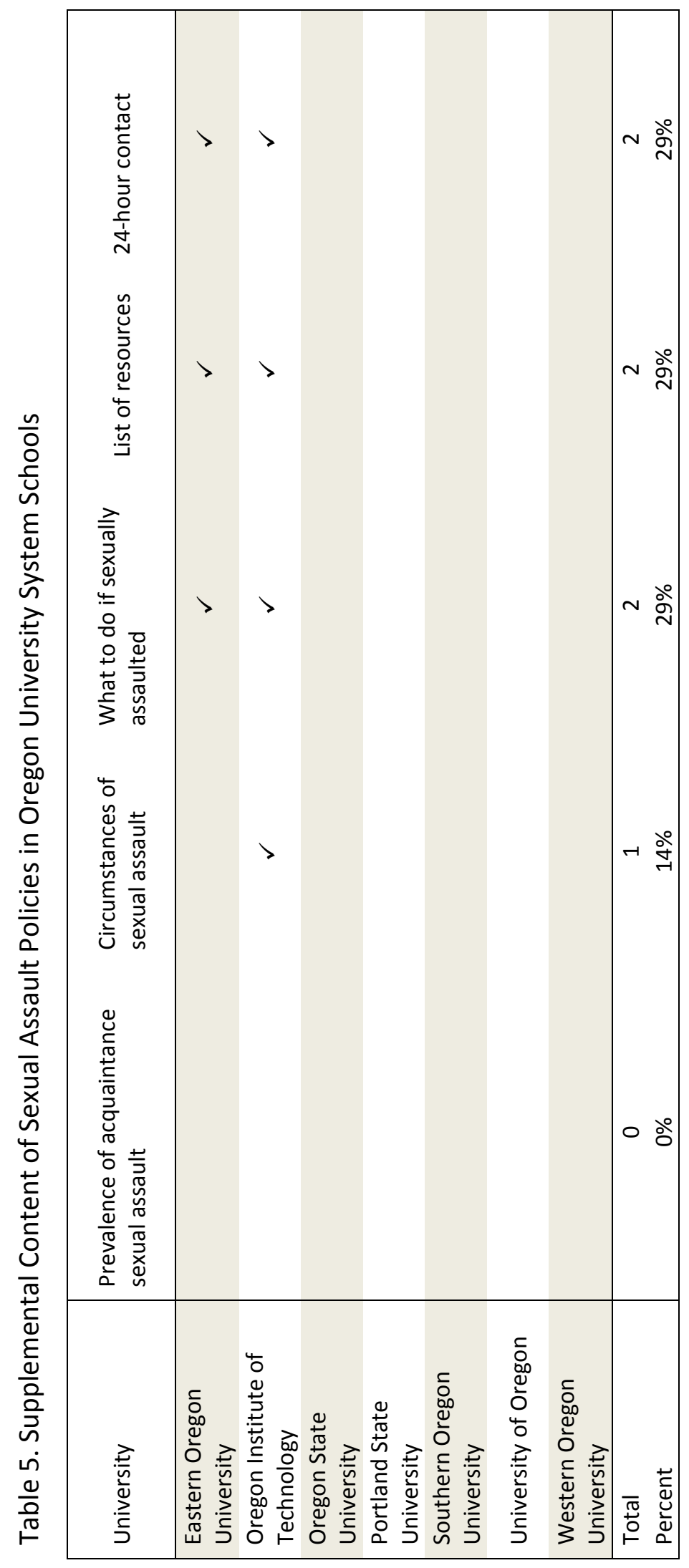




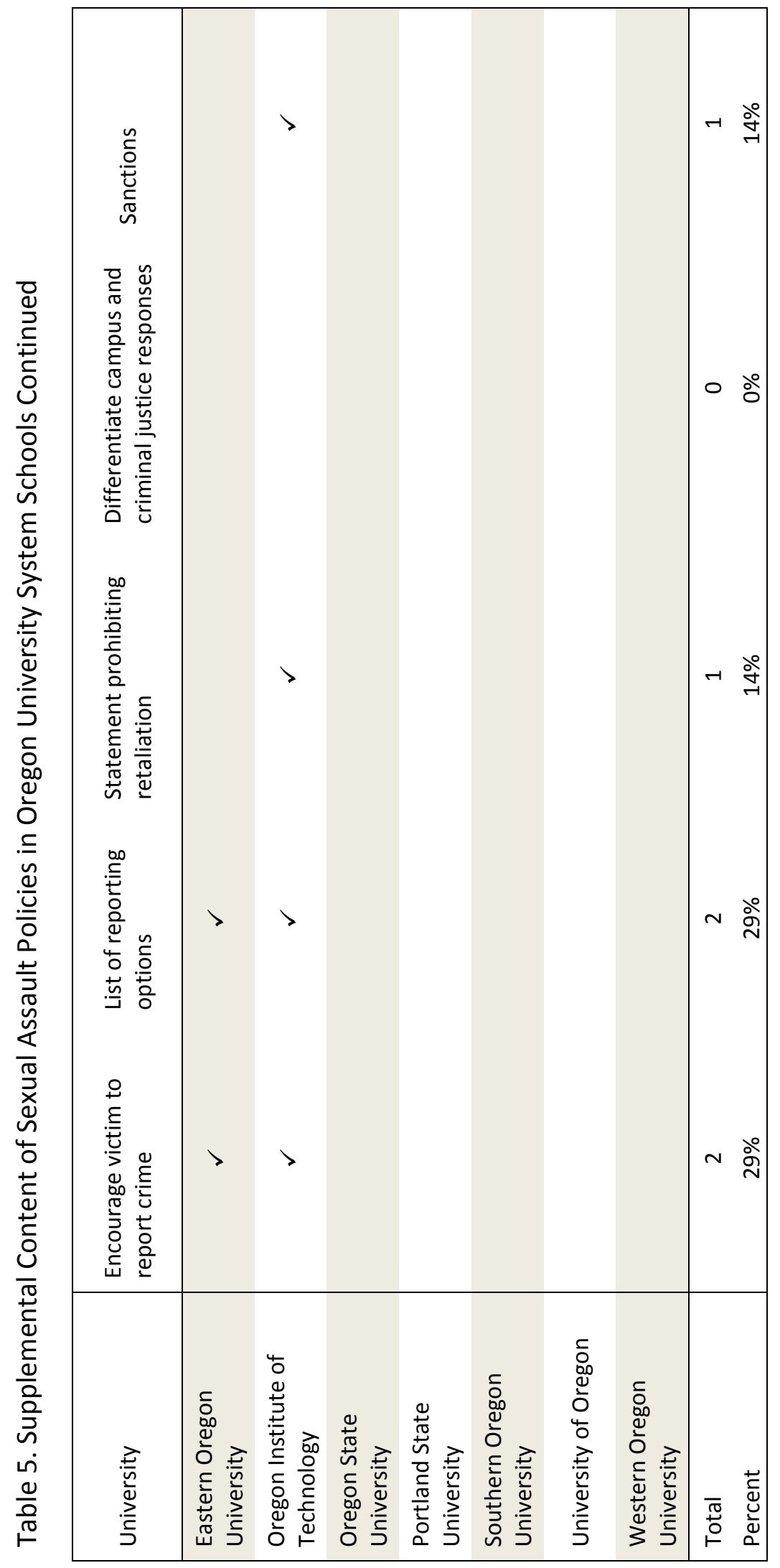




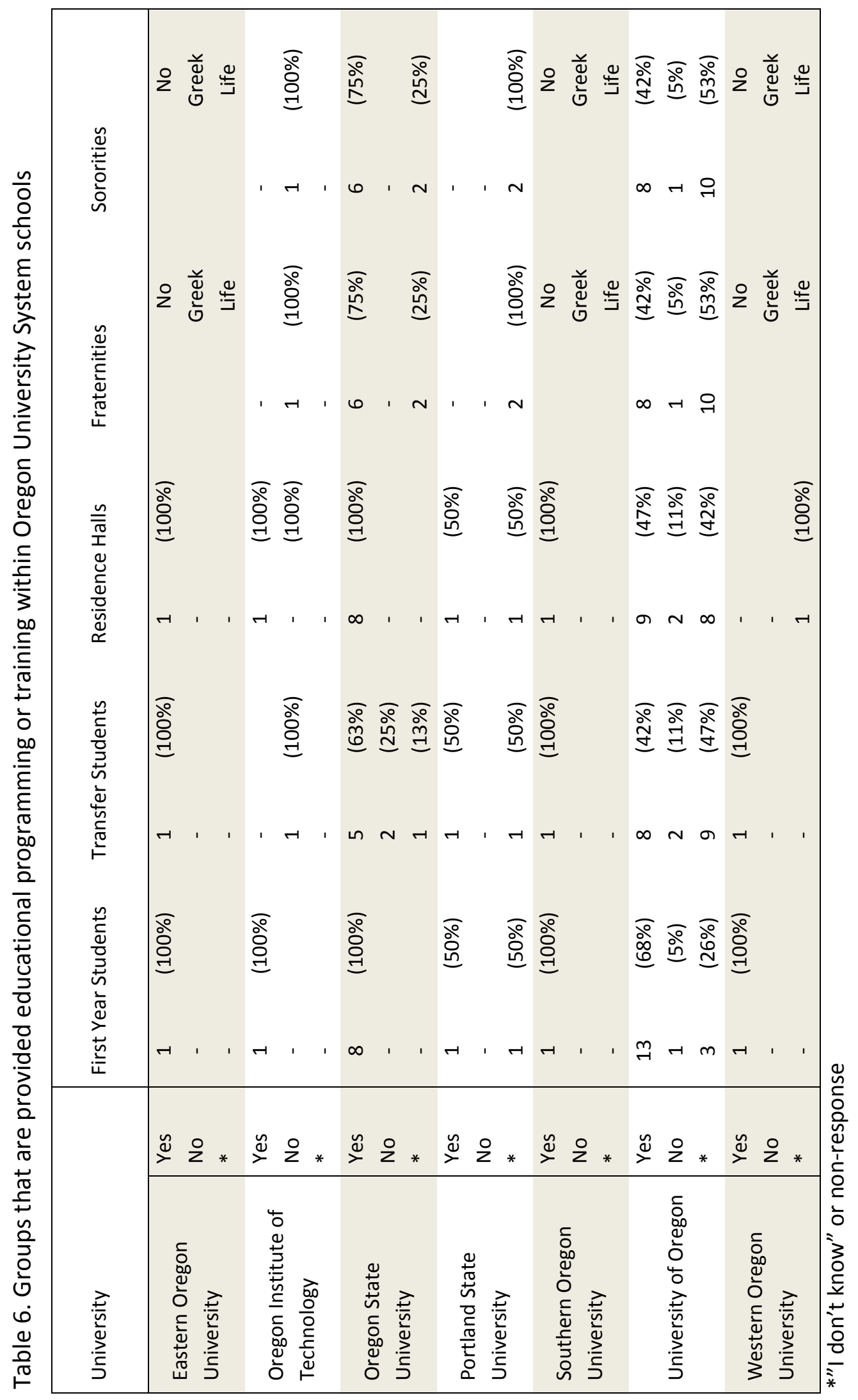




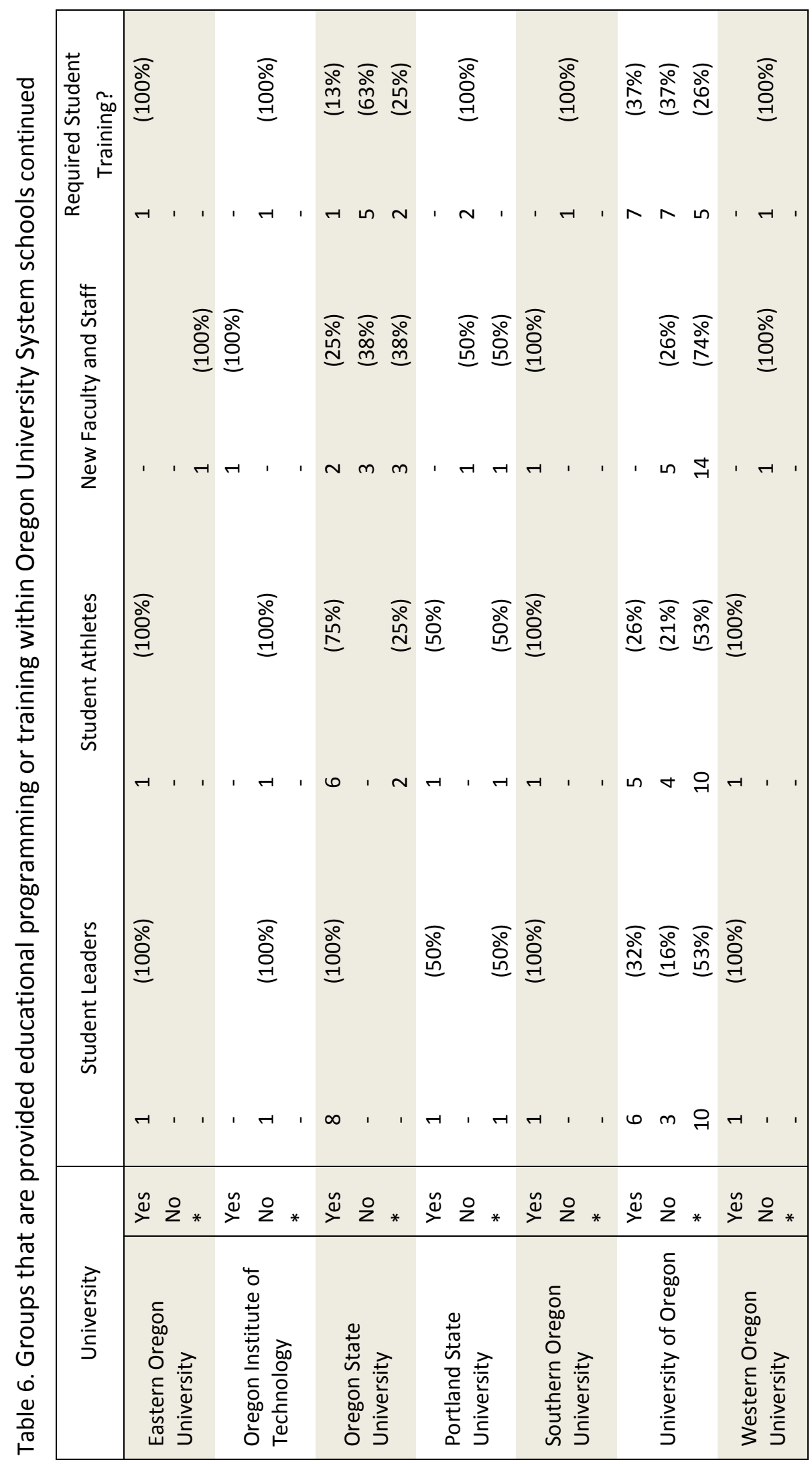


Table 7. Areas that Oregon University System schools would like training and assistance from the Oregon Sexual Assault Task Force

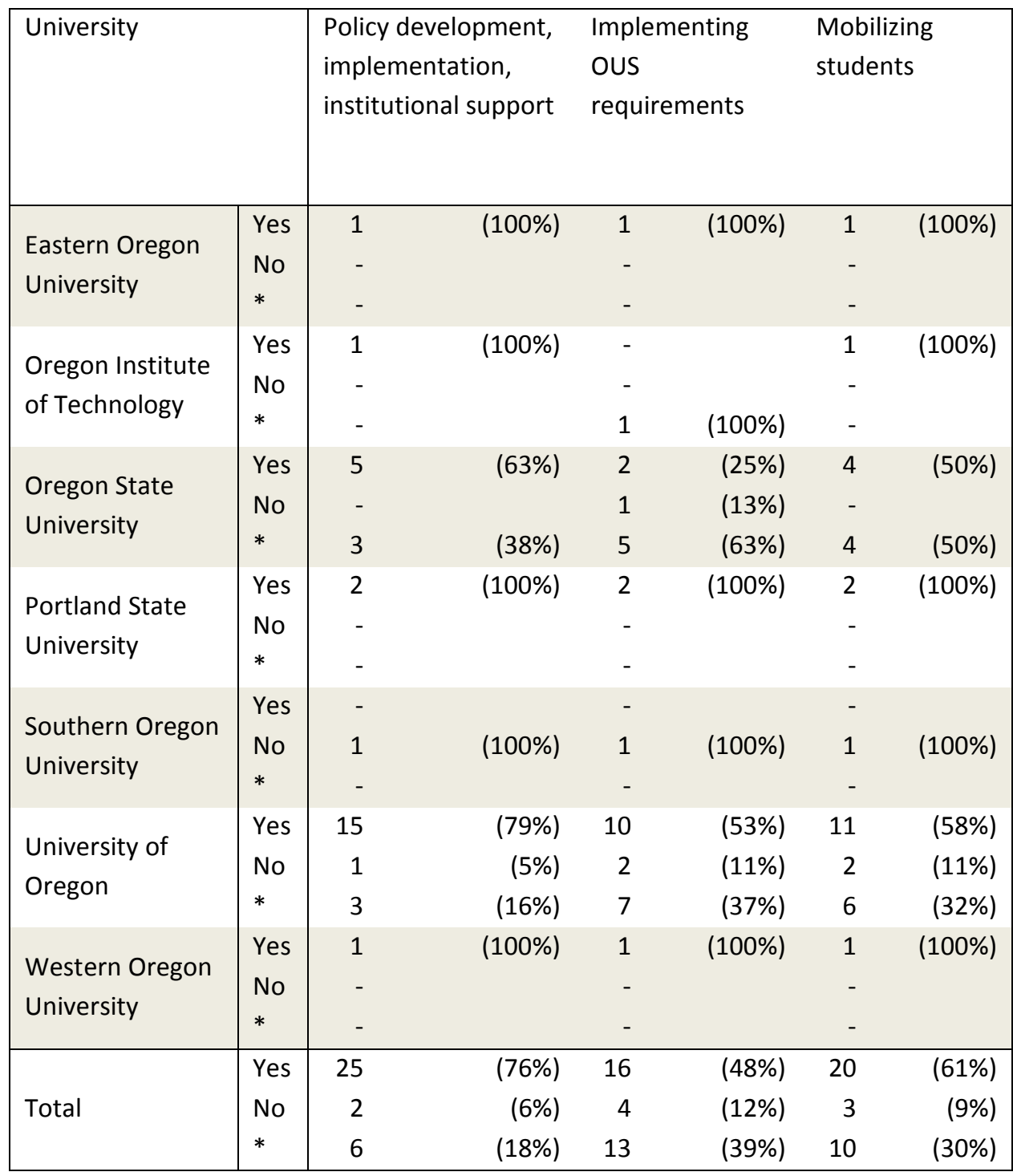

*"I don't know" or non-response 
Table 7. Areas that Oregon University System schools would like training and assistance from the Oregon Sexual Assault Task Force continued

\begin{tabular}{|c|c|c|c|c|c|}
\hline \multicolumn{2}{|l|}{ University } & \multicolumn{2}{|l|}{ Campus SART } & \multicolumn{2}{|c|}{$\begin{array}{l}\text { Campus based sexual } \\
\text { assault prevention }\end{array}$} \\
\hline $\begin{array}{l}\text { Eastern Oregon } \\
\text { University }\end{array}$ & $\begin{array}{l}\text { Yes } \\
\text { No } \\
*\end{array}$ & $\begin{array}{l}1 \\
- \\
-\end{array}$ & $(100 \%)$ & $\begin{array}{l}- \\
- \\
1\end{array}$ & $(100 \%)$ \\
\hline $\begin{array}{l}\text { Oregon Institute } \\
\text { of Technology }\end{array}$ & $\begin{array}{l}\text { Yes } \\
\text { No } \\
*\end{array}$ & $\begin{array}{l}- \\
- \\
1\end{array}$ & $(100 \%)$ & $\begin{array}{l}- \\
- \\
1\end{array}$ & $(100 \%)$ \\
\hline $\begin{array}{l}\text { Oregon State } \\
\text { University }\end{array}$ & $\begin{array}{l}\text { Yes } \\
\text { No } \\
*\end{array}$ & $\begin{array}{l}5 \\
- \\
3\end{array}$ & $\begin{array}{l}(63 \%) \\
(38 \%)\end{array}$ & $\begin{array}{l}6 \\
- \\
2\end{array}$ & $\begin{array}{l}(75 \%) \\
(25 \%)\end{array}$ \\
\hline $\begin{array}{l}\text { Portland State } \\
\text { University }\end{array}$ & $\begin{array}{l}\text { Yes } \\
\text { No } \\
*\end{array}$ & $\begin{array}{l}1 \\
- \\
1\end{array}$ & $\begin{array}{l}(50 \%) \\
(50 \%)\end{array}$ & $\begin{array}{l}2 \\
- \\
-\end{array}$ & $(100 \%)$ \\
\hline $\begin{array}{l}\text { Southern Oregon } \\
\text { University }\end{array}$ & $\begin{array}{l}\text { Yes } \\
\text { No } \\
*\end{array}$ & $\begin{array}{l}- \\
- \\
1\end{array}$ & $(100 \%)$ & $\begin{array}{l}- \\
- \\
1\end{array}$ & $(100 \%)$ \\
\hline $\begin{array}{l}\text { University of } \\
\text { Oregon }\end{array}$ & $\begin{array}{l}\text { Yes } \\
\text { No } \\
*\end{array}$ & $\begin{array}{l}9 \\
2 \\
8\end{array}$ & $\begin{array}{l}(47 \%) \\
(11 \%) \\
(42 \%)\end{array}$ & $\begin{array}{r}7 \\
2 \\
10\end{array}$ & $\begin{array}{l}(37 \%) \\
(11 \%) \\
(53 \%)\end{array}$ \\
\hline $\begin{array}{l}\text { Western Oregon } \\
\text { University }\end{array}$ & $\begin{array}{l}\text { Yes } \\
\text { No } \\
*\end{array}$ & $\begin{array}{l}1 \\
- \\
-\end{array}$ & $(100 \%)$ & $\begin{array}{l}1 \\
- \\
-\end{array}$ & $(100 \%)$ \\
\hline Total & $\begin{array}{l}\text { Yes } \\
\text { No } \\
*\end{array}$ & $\begin{array}{r}17 \\
2 \\
14\end{array}$ & $\begin{array}{r}(52 \%) \\
(6 \%) \\
(42 \%)\end{array}$ & $\begin{array}{r}16 \\
2 \\
15\end{array}$ & $\begin{array}{r}(48 \%) \\
(6 \%) \\
(45 \%)\end{array}$ \\
\hline
\end{tabular}




\section{References}

Bohmer, C., \& Parrot, A. (1993). Sexual assault on campus: The problem and the solution. New York, NY: Lexington Books.

Combs-Lane, A. M., \& Smith, D. W. (2002). Risk of sexual victimization in college women: The role of behavioral intentions and risk-taking behaviors. Journal of Interpersonal Violence, 17, 165-183.

Crawford, E., Wright, M. O., \& Birchmeier, Z. (2008). Drug-facilitated sexual assault: College women's risk of perception and behavioral choices. Journal of American College Health, 57, 261-272.

Daigle, L. E., Fisher, B. S., \& Stewart, M. (2009). The effectiveness of sexual victimization prevention among college students: A summary of "what works". Victims and Offenders, 4, 398-404.

Diener, E., \& Suh, E. (1997). Measuring quality of life: Economic, social and subjuective indicators. Social Indicators Research, 40, 189-216.

Fisher, B. S., Cullen, F. T., \& Turner, M.G. (2000). The sexual victimization of college women: A national-level analysis (Final Report). Washington, DC: U.S. Department of Justice, National Institute of Justice.

Fisher, B. S., Daigle, L. E., \& Cullen, F. T. (2010). Unsafe in the ivory tower: The sexual victimization of college women. Thousand Oaks, CA: SAGE Publications Inc. 
Gidycz, C. A., Layman, M. J., Rich, C. L., Crothers, M., Gylys, J., Matorin, A., \& Jacobs, C. D. (2001). An evaluation of an acquaintance rape prevention program: Impact on attitudes, sexual aggression and sexual victimization. Journal of Interpersonal Violence, 16(11), 1120-1138.

Hanson, K. A., \& Gidycz, C. A. (1993). Evaluation of a sexual assault prevention program. Journal of Consulting and Clinical Psychology, 61(6), 1046-1052.

Harned, M. S. (2004). Does it matter what you call it? The relationship between labeling unwanted sexual experiences and distress. Journal of Consulting and Clinical Psychology, 72, 1090-1099.

Hickman, S. E., \& Muehlenhard, C. L. (1997). College women's fears and precautionary behaviors relating to acquaintance rape and stranger rape. Psychology of Women Quarterly, 21, 527-547.

Jeanne Clery Disclosure of Campus Security Policy and Campus Crime Statistics Act, 20 U.S.C. § 1092(f) (1998).

Karjane, H. M., Fisher, B. S., \& Cullen, F. T. (2001). Campus sexual assault: How America's institutions of higher education respond (NCJ 205521-Final Report). Washington, DC: U.S. Department of Justice, National Institute of Justice. 
Karjane, H. M., Fisher, B. S., \& Cullen, F. T. (2005). Sexual assault on campus: What colleges and universities are doing about it. Washington, DC: U. S. Department of Justice, National Institute of Justice.

Koss, M. P., Gidycz, C. A., \& Wisniewski, N. (1987). The scope of rape: Incidence and prevalence of sexual aggression and victimization in a national sample of higher education students. Journal of Counseling and Clinical Psychology, 55, 162-170.

Marx, B. P., Calhoun, K. S., Wilson, A. E., \& Meyerson, L. A. (2001). Sexual revictimization prevention: An outcome evaluation. Journal of Consulting and Clinical Psychology, 69, 25-32.

Messman-Moore, T. L., \& Brown, A. L. (2006). Risk perception, rape and sexual revictimization: A prospective study of college women. Psychology of Women Quarterly, 30, 159-172.

Oregon Attorney General's Sexual Assault Task Force. (2009). Sexual assault response team handbook (Version III). Salem, OR: Oregon Department of Justice, Oregon Sexual Assault Task Force.

Oregon Attorney General's Sexual Assault Task Force. (2010). Campus Assessment 2010. Salem, OR: Oregon Department of Justice, Oregon Sexual Assault Task Force. 
Oregon State Board of Higher Education - Oversight Committee on Sexual Assault. (2009). Oregon University System Values Document.

Schwartz, M. D. \& DeKeseredy, W. S. (1997). Sexual assault on the college campus: The role of male peer support. Thousand Oaks, CA: SAGE Publications.

Schwartz, M. D., \& Pitts, V. L. (1995). Exploring the feminist routine activities approach to explaining sexual assault. Justice Quarterly, 12, 9-31.

Warshaw, R. (1998). I never called it rape: The Ms. report on recognizing, fighting and surviving date and acquaintance rape. New York, NY: Harper \& Row. 


\section{Appendix A: Definitions of Sexual Assault - Content Analysis Tool}

Generic terms used-not specific types noted/mentioned/listed: sexual assault, sexual offense

$0=$ No $\quad 1=$ Yes

Penile-Vaginal Rape-sexual intercourse (i.e., penile-vaginal) that is perpetrated against the will of the victim or occurs when she/he is unable to give consent and may involve physical violence, coercion, or threat of harm to the victim $0=$ No $\quad 1=$ Yes Other forms of vaginal intercourse-mouth, tongue, hand, or the introduction of a foreign object into the genitals of another person

$0=$ No $\quad 1=$ Yes

Other forms of sexual intercourse-anal or oral penetration with penis, mouth, tongue, hand, fingers, or the introduction of a foreign object

$0=$ No $1=$ Yes

Acquaintance rape-rape by a non-stranger which could include a friend, acquaintance, family member, neighbor, or co-worker

$0=$ No $1=$ Yes

Date rape-rape by someone the victim has been or is dating

$0=$ No $1=$ Yes

Gang acquaintance /date rape-rape by more than one person, at least one of whom is known to the victim

$0=$ No $\quad 1=$ Yes

Sexual contact/Forcible fondling/Sexual battery-unwanted touching of intimate body parts

$0=$ No $1=$ Yes

Incest or Statutory Rape

$0=$ No $1=$ Yes

Other types of sexual offenses-e.g., voyeurism, indecent exposure

$0=$ No $1=$ Yes 
Appendix B: Definitions of Non-Consent - Content Analysis Tool

Generic terms used-not specific types noted/mentioned/listed: without consent, non-consensual

$0=$ No $\quad 1=$ Yes

Forcible - physical force as non-consent

$0=$ No $1=$ Yes

Intoxication - alcohol or drug impairment as non-consent

$0=$ No $\quad 1=$ Yes

Mental Illness - mental illness which prevents victim from giving consent

$0=$ No $\quad 1=$ Yes

Physical Impairment - physical impairment which prevents victim from giving consent

$0=$ No $1=$ Yes 
Appendix C: Supplemental Content of Sexual Assault Policies - Content Analysis

\section{Tool}

Prevalence of acquaintance sexual assault - statistic provided or statement of the prevalence of acquaintance rape

$0=$ No $1=$ Yes

Circumstance of acquaintance sexual assault - statement capturing aspects of acquaintance sexual assault - the use of alcohol, offender known to the victim, force may not used

$0=$ No $1=$ Yes

What to do if sexually assaulted - statement describing steps to take if the victim or someone known to the victim has been sexually assault

$0=$ No $\quad 1=$ Yes

List of community resources

$0=$ No $\quad 1=$ Yes

24-hour contact - statement about which contacts are 24-hour operations

$0=$ No $1=$ Yes

Encourage victim to report crime - statement encouraging the victim to report their victimization

$0=$ No $\quad 1=$ Yes

List of reporting options

$0=$ No $\quad 1=$ Yes

Statement prohibiting retaliation against the reporting victim

$0=$ No $\quad 1=$ Yes

Sanctions - List of sanctions specific to an offender found to have committed sexual assault

$0=$ No $1=$ Yes 
Appendix D: Oregon Sexual Assault Task Force - 2010 Campus Assessment Survey

1. Demographics

1. What is the name of the college or university that you are affiliated with?

O

2. How are you involved on campus?

o Academic Department

o Athletics Department

o Campus Safety/Security/Police

o Counseling Center

o Dean of Students

o Equal Opportunity/Affirmative Action

o Greek Life

o Health Center

o Resident Life

o Student Activities

o Student Conduct/Judicial Affairs

o Student Housing

o Student Organizations

o Student Orientation

o Women's Center

o Other (please specify)

3. Check all that apply. I am a:

o Faculty member

o Staff member

o Student

o Other (please specify)

4. What is your role in responding to or addressing sexual assault cases on campus? Please explain.

O

2. Sexual Assault Policy

1. Does your campus have a sexual assault policy that you are aware of?

o Yes

O No

ol don't know 
2. Does your campus have a sexual assault protocol that you are aware of?

$$
\begin{aligned}
& \text { o Yes } \\
& \text { o No } \\
& \text { ol don't know }
\end{aligned}
$$

3. How is information regarding your campus sexual assault policy, protocol, and conduct/judicial processes disseminated to:

$$
\begin{aligned}
& \text { o Students } \\
& \text { o Faculty } \\
& \text { o Staff }
\end{aligned}
$$

4. Would you be interested in training and/or assistance from the Sexual Assault Task Force to help develop sexual assault policies, get institutional support, and implement policies and protocols campuswide?

$$
\begin{aligned}
& \text { o Yes } \\
& \text { o No } \\
& \text { ol don't know } \\
& \text { o Comments }
\end{aligned}
$$

5. Are you aware of the recent OUS requirements about sexual assault?

$$
\begin{aligned}
& \text { o Yes } \\
& \text { o No }
\end{aligned}
$$

6. Would you be interested in assistance implementing these requirements?

$$
\begin{aligned}
& \text { o Yes } \\
& \text { o No } \\
& \text { ol don't know }
\end{aligned}
$$

3. Faculty and Staff Sexual Assault Training

1. Does your campus provide training about sexual assault to:

$\begin{array}{ll}\text { o Student Leaders/Groups: } & \text { Yes / No / I don't know } \\ \text { o New Faculty: } & \text { Yes / No / I don't know } \\ \text { o New Staff: } & \text { Yes / No / I don't know } \\ \text { o Other: } & \text { Yes / No / I don't know - }\end{array}$

If you selected "other" please specify:

2. How many hours of sexual assault training do you receive each year? O

3. Who provides sexual assault training to your faculty and staff? 
4. Does your campus require sexual assault training for students? Please explain.
o Yes
o No
ol don't know
o Please explain.

4. Educational Programming on Sexual Assault

1. Does your campus provide sexual assault training to:

$\begin{array}{ll}\text { o First year students } & \text { Yes / No / I don't know } \\ \text { o Transfer students } & \text { Yes / No / I don't know } \\ \text { o Residence halls } & \text { Yes / No / I don't know } \\ \text { o Fraternities } & \text { Yes / No / I don't know } \\ \text { o Sororities } & \text { Yes / No / I don't know } \\ \text { o Student Leaders/Groups } & \text { Yes / No / I don't know } \\ \text { o Student Athletes } & \text { Yes / No / I don't know } \\ \text { o New Faulty and Staff } & \text { Yes / No / I don't know } \\ \text { o Other } & \text { Yes / No / I don't know } \\ \text { o Other (please specify) } & \end{array}$

2. Who provides educational programming on sexual assault issues to your faculty/staff/students?

O

3. What student populations do you currently prioritize for sexual assault educational programming? (select all that apply)
o First-year Students
o Transfer Students
o Residence Halls
o Fraternities and Sororities
o Student leaders/groups
o Student athletes
o Other (please specify)

4. To which additional student populations would you like to provide sexual assault educational programming?

5. Student Mobilization to Address Sexual Assault 
1. How knowledgeable about sexual violence do you consider your student population as a whole?

$$
\begin{aligned}
& \text { o Very knowledgeable } \\
& \text { o Knowledgeable } \\
& \text { o Somewhat knowledgeable } \\
& \text { o Lacking } \\
& \text { o Severely lacking }
\end{aligned}
$$

2. Are there student organizations on your campus that are involved in sexual assault prevention or response? Please list those organizations and explain their functions.

0

○

○

$\circ$

○

O

3. What are your current efforts to engage and organize students around response to and prevention of sexual violence?

O

4. Would you like help with efforts to mobilize students around sexual assault prevention and/or response?

$$
\begin{aligned}
& \text { o Yes } \\
& \text { o No } \\
& \text { ol don't know } \\
& \text { o Please explain. }
\end{aligned}
$$

6. Coordinated Campus Response to Sexual Assault.

1. What do you perceive as the strengths and weaknesses of your sexual assault response efforts?

○

2. Has your campus developed or attempted to develop a Campus SART (Sexual Assault Response Team)?

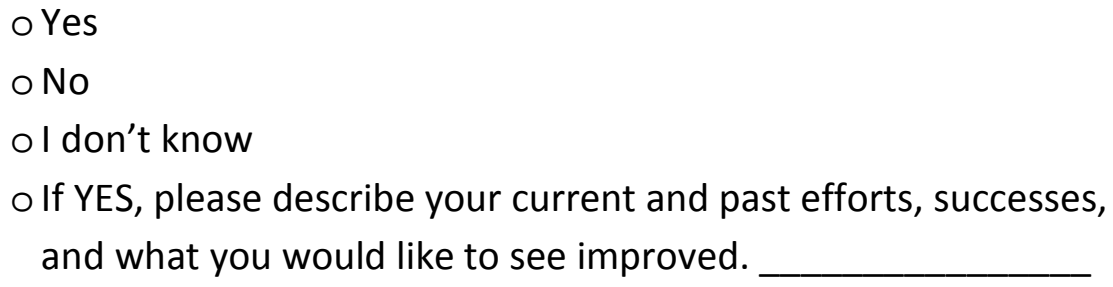


3. Would you be interested in receiving Campus SART training and technical assistance from the Sexual Assault Task Force?

$$
\begin{aligned}
& \text { o Yes } \\
& \text { o No } \\
& \text { ol don't know } \\
& \text { o Comments. }
\end{aligned}
$$

7. Sexual Assault Prevention on Campus

1. What do you perceive as the strengths and weaknesses of your sexual assault prevention efforts?

O

2. Has your campus developed or attempted to develop a Campus prevention coalition, team, or task force?

$$
\begin{aligned}
& \text { o Yes } \\
& \text { o No } \\
& \text { ol don't know } \\
& \text { o Please explain. }
\end{aligned}
$$

3. Has your campus conducted comprehensive sexual assault prevention campaigns and/or initiatives?

$$
\begin{aligned}
& \text { o Yes } \\
& \text { o No } \\
& \text { ol don't know } \\
& \text { o Please explain. }
\end{aligned}
$$

4. Please describe your current and past efforts, success, and what you would like to see improved.

5. Would you be interested in receiving training and assistance on campus-based sexual assault prevention from the Sexual Assault Task Force?

$$
\begin{aligned}
& \text { o Yes } \\
& \text { o No } \\
& \text { ol don't know } \\
& \text { o Comments }
\end{aligned}
$$

8. Follow Up

1. Can we contact you to ask follow-up questions?

$$
\begin{aligned}
& \circ \text { Yes } \\
& \circ \text { No }
\end{aligned}
$$

9. Contact Info 
1. Name:

2. Position:

O

3. Email address:

O

4. Would you like your email address added to the Oregon Campus Men Against Violence listserv? (a group of campus community members all over Oregon that is committed to engaging men in sexual assault prevention)

o Yes

o No

5. Would you like to be added to the statewide campus listserv on sexual assault (a group of campus community members involved in sexual assault prevention and response)?

o Yes

o No

6. Phone number:

O 